\title{
An Analysis of Postgraduates' Information Literacy and Academic Ethics
}

\author{
Xiang Tai \\ The Department of Postgraduate, \\ Yunnan Normal University, YNNU \\ Kunming, Yunnan Province, China \\ Email:xiangtai0408@126.com
}

\begin{abstract}
The development of graduates' information literacy is inevitably connected with their academic morality, so more attention should be paid to combining them in education of graduates. This thesis both analyzes the role of information literacy and problems in five aspects, meanwhile, it also proposes some measures to solve them. This electronic document is a "live" template. The various components of your paper [title, text, heads, etc.] are already defined on the style sheet, as illustrated by the portions given in this document.
\end{abstract} Ethics

Keywords- Postgraduate; Information Literacy; Academic

\section{INTRODUCTION}

Modern postgraduate education requires student to have the ability of filtering and rapidly accessing information, accurately identifying authenticity and creatively processing information etc.[1]. Yet, in the first place, university should emphasize the ability of information creativity on the basis of having a higher information consciousness and morality. In recent years, numerous universities and colleges have involved in academic corruption, project fraud, and plagiarism and so forth[2]. Some academic moral problems of postgraduates and tutors may be caused by the lack of information literacy. In universities, the training of postgraduates' information literacy is easily overlooked. Therefore, to enhance postgraduate information literacy and academic ethics becomes an important issue which cannot be ignored in the postgraduate education [3].

\section{AN OVERVIEW OF POST GRADUATES' ACADEMIC ET HICS} AND INFORMATION LITERACY

Academic ethics refers to the moral code by which scholars and students should abide when engaging in research work and academic activities [4]. Postgraduates' academic moral construction and the entire academia's moral construction are mutual premises and conditions. And the purpose of that is to develop the new academic force who possesses a strong moral consciousness, understands fully the relevant academic norms and has the capacity of moral behavior, and finally brings the reform of moral construction in academic circle so as to provide some moral oxygen for establishing an academic ecosystem with a virtuous cycle and sustainable development.

The concept of information literacy was first proposed by Paul Zurkowski in 1974, who is the then chairman of
American Information Industry Association. He deemed that information literacy was the technology and skill of wielding the information in solving some problems [5]. The Prague Declaration, released by experts of information literacy in 2003 international conference, declared a clearer and more specific interpretation about the connotation of information literacy, which should include the knowledge to the importance and necessity of information and the ability of identifying, searching, assessing, organizing, effectively producing, utilizing and exchanging information in resolving problems [6]. In the last few years, with the spread of information education, information literacy began to attract people's attention and launched a wide discussion about its connotation. In a word, the current domestic understanding can be generalized as information consciousness, information capacity and information ethics [7].

\section{THE EDUCATION OF POST GRADUATES' INFORMATION LITERACY BEING CRITICAL IN THE PROCESS OF CULTIVATION}

The target of graduate education is to foster senior professionals with innovative spirit, and carry out scientific research, teaching and management, or the technical expertise to work independently in specific fields. The education of information literacy is not only a significant means to improve learning quality, but also a major approach to cultivate research and innovation ability. The academic level of postgraduates depends on not only the quality and quantity of relevant academic information they grasp, but also their ability to make an innovation to resolve relevant issues based on the accumulation of academic information[3].

As a potential strength in the scientific field, postgraduates should expand their knowledge by employing information resource, and deepening their academic research with the critical thinking, in which information literacy plays a vital role. To some extent, the level of postgraduate information literacy not only determines his or her innovative consciousness and research capacity, but also influences the level of personnel training in university, and then affects the construction of national innovation talent system. In addition, though postgraduates are all adults, the education of information literacy for them might impact their outlook on life and values in some degree. 


\section{THE LACK OF INFORMATION LITERACY EDUCATION CAUSING THE DECLINE OF POST GRADUATES' ACADEMIC ETHICS}

\section{A. University discounting postgraduates'information literacyeducation}

Some universities equate information consciousness education with information capacity education, emphasizing information skill education and despising information literacy education[8]. A number of universities have few or even no courses to enhance students' information literacy without realizing that the training of information literacy is a compulsory part in the entire education. Furthermore, there is no assessment and evaluation for postgraduates' information literacy as a standard they should achieve when graduating.

The absence of campus information environment, such as poor service in library and the lack of information resources in the campus network, leads to weak information consciousness and low information literacy for postgraduates.

\section{B. Insufficient instruction from mentors}

As the person who is mainly responsible for postgraduate cultivation, a mentor should not only instruct the academic research, but also influence students' academic ethics, academic attitude, philosophy and values and so on [8]. Therefore, the level of mentors' information literacy directly affects the formation and development of postgraduates' information literacy. Due to various reasons the instruction of postgraduates do not attract enough attention, which seriously impacts postgraduates' information literacy. Due to the lack of mentors' guide, it may result in disorderly conducts, and then trigger a series of academic moral issues among postgraduates.

\section{The impact of multi-cultures in modern society}

Being the vital group of utilizing and generating information, it is inevitable for postgraduates to be increasingly influenced by multi-cultures. Some negative tendencies including individualism, money worship and hedonism, have been affecting this group. Some adverse ideologies distort their minds and behaviors, as well as their understanding of the relationship of human, nature and society. As a result, the side effect of multi-cultural environment has blocked their development, and impeded the construction of their spirit. To some extent, the lack of information literacy, nowadays, has generated postgraduate's cris is [7].

\section{The lack of evaluation standards and implementation measures}

Currently, the standard for assessing information literacy in higher education in other countries is more mature, which is disparate from Chinese situation. That is to say, there are few standards in China. The evaluation standard for postgraduates' information literacy might be affected by time, region and social environment and so forth. At present, there are no agreed evaluation standards for assessing postgraduates' information literacy, which they should achieve before graduation. And there are also some difficulties in implementing evaluation standards.
Therefore, to establish evaluation standards and produce implementation measures still need further study.

\section{E. The lack of self-learning ability}

Some postgraduates have poor capacity in self-learning, weak information consciousness, obscure learning objectives, and insufficient analysis and poor judgment while facing a flood of information[8,9]. What's more, quite a few postgraduates do not have strong information consciousness and intense demands of information. Although they have innovative thoughts, they are insensible of putting them into practice[1]. They are impatient in learning, wishing a quick success, hoping to get a diploma and a degree for a good job, instead of regarding the learning process as a way to enhance the qualities.

\section{STRENGT HENING POST GRADUATES' INFORMATION LITERACY EDUCATION AND ACADEMIC ETHICS}

\section{A. Giving full play of the mentor's influence}

On the one hand, as the person who is mainly accountable for postgraduate cultivation, mentors burden the inescapable obligation for postgraduates' information literacy education. Thereupon, mentors should give full play of the mentoring influence in scientific practice. In order to exert an effect on postgraduates' information literacy education, mentors must continuously improve their professional information literacy and attach great importance to strengthening information literacy while instructing graduate students. Furthermore, mentors should also play an exemplary role because their information literacy in academic practice may greatly influence their students. In addition, mentors should strengthen their influence on information literacy in teaching of their students, in projects research and thes is supervision [10].

On the other hand, postgraduates' information literacy education should adhere to the principle of the teacher as guidance and students as the center. The premise of developing postgraduates' ability of information literacy is to improve mentors' ability of it. Only when mentors acquire such an ability can it bring throughout every step of postgraduate education, and closely in line with cultivation of innovative education[1].

\section{B. Integrating information literacy education with ideological and political education}

In order to help students establish a correct outlook on life and values, ideological and political education should be reinforced. Except for that, postgraduates need to be prudent, and universities must carry out seriously the State Council's "Opinions on Further strengthening and improving Ideological and Political Education for College Students"[11] and the Ministry of Education's "Several Opinions on Further Strengthening and Improving Ideological and Political Education for Graduate Students "[12]. Universities should attach great attention to political and moral construction, further reinforce academic ethics and academic discipline education, and steer postgraduates to abide by consciously the academic discipline, and foster the lofty academic ethics. 


\section{Perfecting postgraduate training process and management, and improving information construction and service}

- Universities should make information education among postgraduates a compulsory step, and clarify it in cultivation objectives. Courses on information should be provided, so that students can receive systematic training on the related basic knowledge and skills.

- University should increase the investment on hardware for developing postgraduates' information literacy. And the training of information literacy is not restricted by time and location, which can fully motivate students for individualized learning [3].

- Universities should give full play of the existing information resources and library's information. Librarians should teach postgraduates how to use the database and be familiar with the search interface of the database. By introducing the database, librarians can do the discipline-based information literacy training. Furthermore, postgraduates should be guided to fully utilize the academic information resources, so that they can enhance information literacy in practice[3]. It is worth mentioning that the information service offered by professional librarians for certain subjects provides more practical effects than other information services for postgraduates.

\section{Attempting to Set up the System of Evaluation Standards for Information Literacy}

Based on the practical situation, universities can establish the evaluation standards of information literacy when postgraduates graduate. By means of exam assessment, Internet survey and defense, universities can appraise students' ability of information consciousness, information acquisition, information assessment, information organization and process, information use and innovation, and information ethics [13].

\section{E. To fully mobilize postgraduates'learning enthusiasm and initiative}

Universities should fully arouse students' enthusiasm and initiative for self-learning and self-development. In this way, they would be more positive in academic research and master effective researching methods and techniques. Furthermore, postgraduates should have aspiration for information, learn from the trivial, and develop ability in accumulation of knowledge. Only in this way can they systematically acquire knowledge and cultivate rigorous and practical research style. Thereupon, universities must initiate students' ability of selfmanagement and self-thinkling, so that they can enhance information literacy through their own endeavors [7].

\section{CONCLUSIONS}

The development of information literacy is generally neglected in the process of education for graduates, which is also connected with issues about academic morality for graduates and tutors. It is clear that the anomie of academic morality for some graduates is due to lack of development of postgraduates' information literacy, so to promote graduates' information literacy is a critical step to improve academic morality.

\section{REFERENCES}

[1] Han Xin. (2009). A preliminary study on the education for postgraduate'information literacy. Theory Monthly, 10, 184-186.

[2] Chong Qing JiaoTong University. (2012). The case of academic corruption. http://news.cqjtu.edu.cn/show.aspx ?id=14421.

[3] Li Yang. (2007). An analysis of goals and measures for postgraduate information literacy education. Modern Information, $11,219-225$.

[4] Duan Weiwen. (2012). Academic morality and academic norm, BeiJing:China Radio and Television Publishing House ,19-20.

[5] Paul G Zurkowski. (1974). The Information Service Environment: Relationships and Priorities. Related Paper No.5.. Washington D.C.: National Commission on Libraries and Information Science.

[6] The Prague Declaration. (2003). Towards an information leterate society. Prague, Czech Republic. Sep20-23, 2003.

[7] Jiang Jian. (2011). A study on postgraduate information literacy issues and countermeasures analysis of china. Southwest University, 7,22.

[8] Zhang Xiaohua. (2012). On information literacy and strategies for normal university students in western china. Journal of Mudanjiang College of Education, 3,77-78.

[9] Gong Ping \& Yang Yi. (2012). An analysis on education for postgraduate' information literacy. Library and Information Service Online, 12, 21-25.

[10] Shen'Ou. (2008). The discussion of development of post graduates' information literacy, Medical Information, 11, 2005-2006.

[11] The State Council of the People's Republic of China. (2004). Opinions on further strengthening and improving ideological and political education for college students, http://graduate.cqnu.edu.cn/students/ShowArticle.asp?ArticleID=3 $81 \& \mathrm{id}=\mathrm{mn}$.

[12] The State Council of the People's Republic of China. (2010). Several opinions on further strengthening and improving ideological and political education for graduate students, http://www.moe.edu.cn/business/htmlfiles/moe/s6875/201210/xxg k_142974.html, 20101117.

[13] Yu qi. (2013), The study on graduate information literacy evaluatiion index system in web2.0 environment, SouthWest University , 7, 17-29. 